\title{
Bibliografia prac prof. zw. dr hab. Elżbiety Pleszkun-Olejniczakowej
}

\author{
http://dx.doi.org/10.18778/1505-9057.39.17
}

\section{Monografie}

„Muzy rzadko się do radia przyznaja”. Szkice o stuchowiskach i reportażach radiowych, Primum Verbum, Łódź 2012, s. 379.

Dwa teatry. Studia z zakresu teorii i interpretacji sztuki stuchowiskowej, we współautorstwie z J. Bachurą i A. Pawlik, Wydawnictwo Adam Marszałek, Toruń 2011, s. 497.

Stuchowiska Polskiego Radia w okresie piętnastolecia 1925-1939, t. 1: Fakty, wnioski, przypuszczenia [s. 426] oraz t. 2: Rejestr stuchowisk piętnastolecia 1925-1939 [s. 259], Biblioteka, Łódź 2000.

Instytucje literackie w Łodzi międzywojennej i ich rola kulturotwórcza, Biblioteka, Łódź 1996, s. 102.

\section{Artykuły}

E. Pleszkun-Olejniczakowa, K. Szklarek, Radio Łódź - od momentu powstania (1930) po dzień dzisiejszy - na wybranych przykładach, [w:] Radio w cyfrowym świecie. Regionalne rozgłośnie radiowe, red. M. Łyszczarz, M. Sokołowski, Wydawnictwo Uniwersytetu Warmińsko-Mazurskiego, Olsztyn 2016, s. 38-48.

Kulturowy rozwój Łodzi w okresie międzywojennym, „Acta Universitatis Lodziensis. Folia Litteraria Polonica" 2015, nr 3 (29), s. 7-24.

E. Pleszkun-Olejniczakowa, J. Bachura-Wojtasik, K. Klimczak, Stuchowiska na polskiej antenie, czyli o Teatrze Wyobraźni i Teatrze Polskiego Radia, [w:] Polskie Radio. Historia - program-technika. 90 lat Polskiego Radia, red. A. Ossibach-Budzyński, Oficyna Wydawnicza ASPRA-JR, Warszawa 2015, s. 359-390.

„Starość (i śmierć) jest piękna” - na antenie, [w:] Medialne reprezentacje kultury. Literatura - teatr - sztuka - religia, t. 1, red. A. Sugier-Szerega, Wydawnictwo KUL, Lublin 2015, s. 53-65.

What is over is (not) over: Radio as an artist and its audience in Poland, [w:] Radio: the Resilient Medium: Papers from the Third Conference of the ECREA Radio Research Station, red. M. Oliveira, G. Stachyra, G. Starkey, Sunderland: Centre for Research in Media and Cultural Studies, Sunderland 2014, s. 267-279.

Przyczynek do planu klasztoru kultury na podstawie badań radiowych przekazów artystycznych, „Acta Universitatis Lodziensis. Folia Litteraria Polonica” 2014, nr 1 (23), s. 7-42.

E. Pleszkun-Olejniczakowa, K. Grzegorzewska, Encuentro de dos mundos y sistema de valores, [w:] „Annales. Universitatis Mariae Curie-Skłodowska, sectio I. Philosophy and Sociology” 2014, vol. 39, nr 2, s. 39-47. 
E. Pleszkun-Olejniczakowa, J. Bachura, Tymon Terlecki w międzywojennym Teatrze Wyobraźni, „Pamiętnik Teatralny” 2011, z. 3-4, s. 273-290.

E. Pleszkun-Olejniczakowa, K. Klimczak, Poznawanie, przetwarzanie i kreowanie rzeczywistości na podstawie wybranych artystycznych dzieł audialnych, [w:] Poznawać. Tworzyć. Komunikować. Wielokodowość komunikacji, red. A. Barańska, Primum Verbum, Łódź 2011, s. $48-56$.

Kulturowy przekaz radia, [w:] Radio i społeczeństwo, red. G. Stachyra, E. Pawlak-Hejno, Wydawnictwo Uniwersytetu Marii Curie-Skłodowskiej, Lublin 2011, s. 225-242.

O świętości na podstawie wybranych artystycznych tekstów audialnych o Janie Pawle II, [w:] Autorytety w perspektywie chrześcijańskiej, red. B. Bogołębska, M. Worsowicz, Wydawnictwo Uniwersytetu Łódzkiego, Łódź 2011, s. 37-52.

„Pan Cogito biada nad matościa...” słów, czyli o kilku stuchowiskach Zbigniewa Herberta, [w:] Etos życia-Etos sztuki. Wokót legendy o świętym Genezjuszu - aktorze, część 2, red. M. Leyko, K. Wielechowska, Wydawnictwo Uniwersytetu Łódzkiego, Łódź 2010, s. 305-320.

E. Pleszkun-Olejniczakowa, J. Bachura, Rola stuchowisk w komunikacji kulturowej, [w:] Komunikacja i komunikowane w XX-leciu międzywojennym, red. K. Stępnik, M. Rajewski, Wydawnictwo Uniwersytetu Marii Curie-Skłodowskiej, Lublin 2010, s. 155-172.

Biogram Zygmunta Chamca, [w:] Styl - Dyskurs - Media, red. B. Bogołębska, M. Worsowicz, Wydawnictwo Uniwersytetu Łódzkiego, Łódź 2010, s. 13-21.

Łódzka Rozgłośnia Radiowa w latach 1930-1939, [w:] Styl-Dyskurs-Media, red. B. Bogołębska, M. Worsowicz, Wydawnictwo Uniwersytetu Łódzkiego, Łódź 2010, s. 461-470.

Morfologia śledczego reportażu radiowego - struktura gatunku (uwagi wstępne), [w:] O dziennikarstwie śledczym. Normy, zagrożenia, perspektywy, red. M. Palczewski, M. Worsowicz, Wydawnictwo Wyższej Szkoły Humanistyczno-Ekonomicznej w Łodzi, Łódź 2009, s. $195-210$.

W stronę budowania teorii i języka opisu reportażu radiowego. Rozwój bez tajemnic?, [w:] Tajemnice rozwoju, red. D. Bieńkowska, A. Lenartowicz, Archidiecezjalne Wydawnictwo Łódzkie, Łódź 2009, s. 393-406.

Demiurg czy cicerone? O sposobach istnienia stowa i tekstu audialnego na antenie, [w:] Stowo w kulturze współczesnej, red. W. Kawecki, K. Flader, Wydawnictwo Kardynała Stefana Wyszyńskiego, Warszawa 2009, s. 251-272.

Reportaż radiowy jako przedmiot dotychczasowych badań naukowych. Próba określenia przyszłych kierunków, Media - Społeczeństwo - Kultura. Zeszyty Naukowe Wyższej Szkoły Dziennikarskiej im. Melchiora Wańkowicza w Warszawie 2009, nr (2), s. 40-54.

„Reportaż to gra uczuć i emocji”. O reportażach radiowych wspótczesnych twórców Polskiego Radia, [w:] Media studies. Refleksja nad stanem obecnym, red. K. Stępnik, M. Rajewski, Wydawnictwo Uniwersytetu Marii Curie-Skłodowskiej, Lublin 2008, s. 367-376.

Żydzi i Polacy we współczesnym reportażu radiowym, „Acta Universitatis Lodziensis. Folia Litteraria Polonica" 2007, nr 9, s. 379-391.

Herbertowska „Jaskinia Filozofów” Janusza Kukuły oraz „Bo Ty jesteś ze mna” Ireny Piłatowskiej jako audialne dzieła pogranicza, [w:] Pogranicza, red. D. Kowalska, Archidiecezjalne Wydawnictwo Łódzkie, Łódź 2007, s. 547-558.

E. Pleszkun-Olejniczakowa, M. Delida, Tuwim przestuchiwany. O dwu stuchowiskach autora „Kwiatów polskich”, [w:] Julian Tuwim: biografia, twórczość, recepcja, red. K. Ratajska, T. Cieślak, Wydawnictwo Uniwersytetu Łódzkiego, Łódź 2007, s. 195-209. 
E. Pleszkun-Olejniczakowa, K. Klimczak, Świat emocji reportaży radiowych Janiny Jankowskiej, Ireny Piłatowksiej i Anny Sekudewicz, [w:] Wyrażanie emocji, red. K. Michalewski, Wydawnictwo Uniwersytetu Łódzkiego, Łódź 2006, s. 317-326.

Radiowe dziennikarstwo śledcze. Prolegomena do przyszłej syntezy, [w:] Dziennikarstwo śledcze. Teoria i praktyka w Polsce, Europie i Stanach Zjednoczonych, red. M. Palczewski, M. Worsowicz, Wydawnictwo Wyższej Szkoły Humanistyczno-Ekonomicznej w Łodzi, Łódź 2006, s. $135-149$.

Reportaż. Wokót pochodzenia, definicji i podziałów, „Acta Universitatis Lodziensis. Folia Litteraria Polonica" 2005, nr 2, s. 3-27.

Maszyna wkracza w sztukę. Literatura na antenie Polskiego Radia, „Mówią Wieki” 2005, nr 1 specjalny, s. 48-54.

Oreportażu radiowym, [w:] Reportaż w dwudziestoleciu międzywojennym, red. K. Stępnik, M. Piechota, Wydawnictwo Uniwersytetu Marii Curie-Skłodowskiej, Lublin 2004, s. 115-123.

Pojęcie stosowności we wspótczesnym reportażu radiowym (na wybranych przykladach), „Napis” 2004, seria X, s. 289-297.

O funkcjonowaniu tekstu literackiego w radiu (na przyktadzie Polskiego Radia lat 1925-1939), [w:] Tekst w mediach, red. K. Michalewski, Wydawnictwo Uniwersytetu Łódzkiego, Łódź 2002, s. 426-431.

Słowa, głosy, dźwięki w słuchowiskach radiowych, [w:] Język w komunikacji, t. 2, red. G. Habrajska, Wydawnictwo Wyższej Szkoły Humanistyczno-Ekonomicznej w Łodzi, Łódź 2001, s. $54-60$.

„Janina Morawska [...] większq artystka niż Zofia Natkowska”, czyli niespodzianki literackie w Polskim Radiu w okresie piętnastolecia 1925-1939, „Prace Polonistyczne” 2001, s. 155170.

Intencje interpretacyjne wpisane w stuchowiska przy pomocy słów i dźwięków, [w:] Regulacyjna funkcja tekstów, red. K. Michalewski, Wydawnictwo Uniwersytetu Łódzkiego, Łódź 2000, s. 363-370.

Wrowadzenie do rozważań o krytyce stuchowiskowej, „Acta Universitatis Lodziensis. Folia Litteraria Polonica" 1998, nr 1, s. 153-175.

Radio Łodzi nie zaszkodzi, „Tygiel Kultury” 1996, nr 3, s. 75-80.

Czasopisma kulturalne w Łodzi. Dwudziestolecie międzywojenne, „Tygiel Kultury” 1996, nr 4, s. $75-78$.

Środowisko literackie w Łodzi w dwudziestoleciu międzywojennym, „Miscellanea Łódzkie” 1995, nr 2 (14), s. 5-25.

„Czy radio jest XII Muzq" czyli co na temat odrębności stuchowisk radiowych pisano w prasie dwudziestolecia międzywojennego, „Prace Naukowe Wyższej Szkoły Pedagogicznej w Częstochowie”, seria: „Zeszyty Historyczne” 1994, z. 2, s. 255-266.

Złe przeczucia eschatologiczne Pana Herberta, „Prace Polonistyczne” 1993, s. 217-234.

O ,Bogu Spinozy” i innych Bogach, [w:] Dlaczego Herbert. Wiersze i komentarze, red. K. Poklewska, T. Cieślak, J. Wiśniewski, Oficyna Bibliofilów, Łódź 1992, s. 68-81.

Literatura w Polskim Radiu w latach międzywojennych (O Eksperymentalnym Teatrze Wyobraźni), „Prace Polonistyczne” 1990, s. 225-238.

Literatura w Polskim Radiu w okresie międzywojennym, „Prace Polonistyczne” 1989, s. 185-200. Ze zwiazków Berenta z Łodzia, [w:] Studia o Berencie, red. J. Paszek, Wydawnictwo Uniwersytetu Śląskiego, Katowice 1984, s. 132-139. 
Wokót Nagród Literackich w Łodzi w okresie międzywojennym, „Osnowa” 1981, nr 1, s. 94-108. Wyższa Szkoła Nauk Społecznych i Ekonomicznych w Lodzi (1925-1928), „Rocznik Łódzki” 1978, s. 227-249.

Literatura rosyjska w łódzkiej prasie lat 1918-1922, „Przegląd Humanistyczny” 1976, nr 9, s. 87-97. „Sen w Podhorcach”- fantastyczna czy realistyczna nowela Stanistawa Chołoniewskiego, „Prace Polonistyczne" 1973, s. 175-186.

\section{Podręczniki i skrypty - artykuly, redakcje}

Od kreacji do znaczenia (na podstawie wybranych tekstów audialnych), [w:] O mediach i komunikacji. Skrypt dla studentów dziennikarstwa i komunikacji społecznej, red. E. Pleszkun-Olejniczakowa, J. Bachura, M. Worsowicz, Wydawnictwo Uniwersytetu Łódzkiego, Łódź 2010, s. 153-186.

„Dwa Teatry” czyli o Teatrze wyobraźni i Teatrze Polskiego Radia, [w:] Wypowiedź dziennikarska. Teoria i praktyka. Skrypt dla studentów dziennikarstwa, red. B. Bogołębska, A. Kudra, Wydawnictwo Uniwersytetu Łódzkiego, Łódź 2008, s. 157-198.

\section{Recenzje i inne publikacje}

Pleszkun-Olejniczakowa E., Szklarek K., Radio Łódź - od 1930 roku po dziś, „Kronika Miasta Łodzi" 2016, nr 3 (75), s. 57-67.

Odpowiedź na recenzję Wacława Lewandowskiego książki Violetty Wejs-Milewskiej „Radio Europa na emigracyjnych szlakach pisarzy”, „Pamiętnik Literacki” 2011, nr 2, s. 277-284.

Poznawanie słowa. Wyktady inauguracyjne Wydziału Filologicznego UŁ wygłoszone w roku akademickim 2009/2010, Primum Verbum, Łódź 2010, s. 24-60.

Morfologia radiowego reportażu śledczego - struktura gatunku (Uwagi wstęne), [w:] Seminarium reportażu poświęcone prezentacji i dyskusji warsztatowej nad radiowym dokumentem artystycznym, Kazimierz Dolny, 26-28 X 2008, s. 64-75.

Wstęp do morfologii gatunku. Reportaż radiowy jako przedmiot dotychczasowych i przysztych badań naukowych, [w:] Seminarium reportażu poświęcone prezentacji i dyskusji warsztatowej nad radiowym dokumentem artystycznym, Kazimierz Dolny, 21-24 X 2007, s. $71-84$.

Rec. książki K. Tatarowskiego, Literatura i pisarze w programie rozgłośni Polskiej Radio Wolna Europa, „Zagadnienia Rodzajów Literackich” 2007, t. 50, s. 238-242.

Sens i sposób istnienia twórczości przed mikrofonem, [w:] Seminarium reportażu poświęcone prezentacji i dyskusji warsztatowej nad radiowym dokumentem artystycznym, Kazimierz Dolny, 22-24 X 2006, s. 67-86.

Miłość i cierpienie w wybranych reportażach Ireny Piłatowskiej i Anny Sekudewicz, [w:] Seminarium reportażu poświęcone prezentacji i dyskusji warsztatowej nad radiowym dokumentem artystycznym, Kazimierz Dolny, 23-25 X 2005, s. 61-72.

Co wolno, a czego nie wolno reporterowi radiowemu, czyli kryteria stosowności a wolność twórcy, [w:] Seminarium reportażu poświęcone prezentacji i dyskusji warsztatowej nad radiowym dokumentem artystycznym, Kazimierz Dolny, 24-27 X 2004, s. 88-102.

„,Radio to dla nas wyprowadzenie z ciemności”. Łódzka Rozgłośnia Radiowa w latach 1930-1939, „Kronika Miasta Łodzi” 2003, nr 1, s. 71-78. 
O reportażu radiowym - jego pochodzeniu, definicji i próbach podziału, [w:] Seminarium reportażu poświęcone prezentacji i dyskusji warsztatowej nad radiowym dokumentem artystycznym, Kazimierz Dolny, 19-22 X 2003, s. 33-50.

Wstęp do: Emilia Tesz, Rytm serca, Związek Nauczycielstwa Polskiego, Tomaszów Mazowiecki 2000, s. 9-22.

Łódzkie czasopisma literackie i kulturalne. Ze zbiorów Wojewódzkiej i Miejskiej Biblioteki Publicznej im. Marszałka Józefa Piłsudskiego, Dwudziestolecie międzywojenne.

Zofia Lorentz, „Odgłosy” 1975, XVIII, nr 17 (907).

Recenzja pracy Polskaja liryka w pierewodach russkich poetow, Moskwa 1969, „Przegląd Humanistyczny" 1972, nr 4, s. 161-171. 